\title{
PENGEMBANGAN BAHAN AJAR ELEKTRONIK MULTIMEDIA DENGAN MACROMEDIA FLASH 8.0 UNTUK MAHASISWA S1 PGSD UKSW
}

\author{
Wahyudi \\ Program Studi S1 Pendidikan Guru Sekolah Dasar (PGSD) \\ FKIP Universitas Kristen Satya Wacana
}

\begin{abstract}
ABSTRAK
Penelitian ini merupakan penelitian pengembangan dengan desain pengembangan. Borg \& Gall dan Dick \& Carey yang disederhanakan. Sepuluh tahapan yang ada disederhanakan dalam empat tahapan, yaitu: (1) tahap analisis kebutuhan, (2) tahap desain pengembangan bahan ajar, (3) tahap pengembangan dan evaluasi, (4) tahap desiminasi produk akhir. Subjek penelitian yang diambil adalah mahasiswa S1 PGSD kelas G angkatan 2009 untuk uji terbatas (one to one dan small group evaluation) dan uji luas (field trial evaluation) yaitu kelas A 2010. Teknik pengumpulan data menggunakan penilaian pakar (media dan materi) dan uji coba produk. Instrumen yang digunakan adalah lembar validasi pakar, angket tertutup respon mahasiswa terhadap pemanfaatan bahan ajar dalam pembelajaran, lembar observasi untuk melihat proses pembelajaran pada saat uji coba produk, serta soal tes untuk melihat dampak pembelajaran yang digunakan. Hasil penelitian ini menunjukkan bahwa bahan ajar elektronik multimedia dengan macromedia Flash 8.0 yang dibuat memiliki kategori yang baik dari segi materi maupun media. Bahan ajar ini dapat membantu memudahkan mahasiswa belajar tentang sistem persamaan linear tiga variabel. Uji coba dalam pembelajaran menunjukkan bahwa mahasiswa lebih senang belajar matematika. Mahasiswa semakin mudah memahami materi karena bantuan animasi, video, warna dan tampilan yang menarik. Dengan bantuan tek, audio, dan video membuat mahasiswa dapat belajar secara mandiri, sehingga bahan ajar ini cocok digunakan sebagai bahan ajar mandiri yang dapat dibawa dan digunakan dimana-mana dan mahasiswa dapat belajar setiap saat.
\end{abstract}

Kata kunci: bahan ajar elektronik, multimedia, macromedia flash 8, sistem persamaan linear, pembelajaran matematika

\section{PENDAHULUAN}

Kemajuan teknologi saat ini begitu pesat dan berdampak pada kehidupan manusia. Salah satu dampak juga terjadi pada dunia pendidikan dengan memanfaatkan teknologi komputer dan internet sebagai media untuk belajar. Adanya komputer dan internet memudahkan dalam membuat tugas, menghemat waktu, bahkan bisa menambah sumber informasi sebagai sumber belajar. Keadaan ini membuat mahasiswa menjadi semakin cepat dalam menerima dan memperoleh informasi khususnya materi kuliah dan pelajaran.

Kemajuan teknologi membuat media dan sumber belajar menjadi bervariasi dan menarik. Tidak hanya teks dan gambar saja, tetapi ada audio, video, dan animasi yang membuat suatu konsep lebih mudah untuk dipahami. Penyajian informasi dalam beberapa cara dan bentuk itu sering dinamakan multimedia. Secara teknis, multimedia bukan merupakan hal yang baru, karena integrasi teks dan gambar sudah banyak dilakukan dalam banyak aplikasi. Multimedia dapat digunakan untuk menunjang proses manajemen pada berbagai tingkat organisasi. Pengembangan multimedia memerlukan authoring tool seperti Adobe Premiere, Macromedia Director, serta pemrograman menggunakan bahasa pemrograman yang menjadi bagian dari authoring tool, atau bahasa pemrograman yang digunakan secara umum (Ariesto H.S, 2008). 
Dengan authoring tool, dapat dikembangkan multimedia interaktif, di mana animasi yang ditampilkan sesuai dengan hasil operasi matematika maupun logika. Salah satu Authoring tool yang dapat digunakan adalah Macromedia Flash 8.0 yang memiliki kemampuan untuk mengembangkan hampir semua aplikasi multimedia. Harapannya dengan adanya multimedia interaktif, akan mempermudah mahasiswa dalam belajar dan mendapatkan informasi (Ariesto H.S, 2008).

Pembuatan bahan ajar elektronik multimedia dengan Macromedia Flash 8.0 juga diperlukan dalam mata kuliah matematika di Program Studi S1 PGSD UKSW untuk mempermudah penyampaian materi dan pemahaman mahasiswa. Pembuatan bahan ajar elektronik multimedia dilatar belakangi oleh keberadaan matematika sebagai ilmu yang saling berkait sehingga pemahaman konsep yang salah akan berakibat pada kesalahan terhadap pemahaman konsep selanjutnya (Cahya Prihandoko, 2006).

Matematika juga memberikan kontribusi positif tercapainya masyarakat yang cerdas dan bermartabat melalui sikap kritis dan berpikir logis (Suminarsih, 2007). Berdasarkan hal tersebut maka matematika dipilih menjadi salah satu mata pelajaran yang diberikan di ketiga tingkat pendidikan di Indonesia, yaitu pendidikan dasar (Sekolah Dasar/SD dan Sekolah Menengah Pertama/SMP), dan pendidikan menengah (Sekolah MenengahAtas/SMA). Menurut Depdikbud yang dikutip oleh Suharno (2004), matematika yang diberikan di pendidikan tingkat dasar sampai tingkat menengah disebut juga dengan matematika sekolah.

Kenyataan yang telah dilakukan, pembelajaran matematika di Program Studi S1 PGSD UKSW masih mengandalkan cara lama yaitu cara mekanistik. Pembelajaran ini hanya mengandalkan penjelasan dosen dan latihan soal yang dilakukan oleh mahasiswa. Pembelajaran yang dilakukan kurang menuntut mahasiswa untuk aktif dalam pembelajaran, mereka cenderung menerima dan pasif. Pemanfaatan pembelajaran ICT (e-learning) yaitu Flexible Learning belum dilakukan secara maksimal. Bahan ajar yang tersedia masih didominasi oleh teks dan gambar saja. Pembelajaran masih belum begitu menarik meskipun sudah memanfaatkan komputer dan internet sebagai media dan sumber belajar.

Untuk mengatasi hal tersebut, maka dalam penelitian ini akan dikembangkan bahan ajar elektronik multimedia dengan Macromedia Flash 8.0. Bahan ajar ini akan dikemas dalam bentuk CD yang bisa digunakan waktu pembelajaran di kampus maupun dibawa pulang oleh mahasiswa untuk dipelajari di rumah. Bahan ajar ini nantinya akan dikombinasi dengan Flexible Learning sebagai sarana kegiatan pembelajaran online untuk mata kuliah Konsep Dasar Matematika bagi mahasiswa S1 PGSD FKIP UKSW. Pembelajaran akan dilaksanakan di laboratorium komputer Universitas Kristen Satya Wacana.

\section{TINJAUAN PUSTAKA}

\section{Bahan Ajar Berbasis Multimedia}

\section{Pengertian Bahan Ajar}

Banyak sumber yang mengatakan pengertian tentang bahan ajar. Dalam penelitian ini mengambil dua definisi yaitu dari Andi Sapta (2009) dan Dick \& Carey (1996). Menurut Andi Sapta (2009) bahan ajar adalah segala bentuk bahan yang digunakan untuk membantu pengajar/instruktur dalam melaksanakan kegiatan belajar mengajar. Bahan yang dimaksud bisa berupa bahan tertulis maupun bahan tidak tertulis. Menurut Dick \& Carey (1996) merupakan seperangkat materi/substansi pelajaran (teaching material) yang disusun secara sistematis, menampilkan sosok utuh dari kompetensi yang akan dikuasai oleh peserta didik dalam kegiatan pembelajaran.

Berdasarkan dua definisi ini maka dapat diambil sebuah definisi tentang bahan ajar yaitu segala bentuk bahan yang tersusun secara sistematis yang memuat tentang kompetensi yang harus dikuasai dan akan dicapai/dikuasai peserta didik setelah melalui proses pembelajaran. Dengan bahan ajar memungkinkan 
peserta didik dapat mempelajari suatu kompetensi secara runtut dan sistematis sehingga secara akumulatif mampu menguasai semua kompetensi secara utuh dan terpadu.

Fungsi bahan ajar secara umum, yaitu:

a. Pedoman bagi pengajar yang akan mengarahkan semua aktivitasnya dalam proses pembelajaran, sekaligus merupakan substansi kompetensi yang seharusnya diajarkan kepada peserta didik.

b. Pedoman bagi peserta didik yang akan mengarahkan semua aktivitasnya dalam proses pembelajaran, sekaligus merupakan substansi kompetensi yang seharusnya dipelajari/ dikuasainya.

c. Alat evaluasi pencapaian/penguasaan hasil pembelajaran.

\section{Pengertian Media dan Multimedia}

Kata media secara harfiah berarti perantara atau pengantar. Menurut Briggs, media adalah "alat untuk memberi perangsang bagi peserta didik supaya terjadi proses belajar. Sedangkan mengenai efektifitas media, Brown (1970) dalam Asra, Deni Darmawan \& Cepi Riana (2007) menggaris bawahi bahwa media yang digunakan dengan baik oleh pengajar atau peserta didik dapat mempengaruhi efektifitas proses belajar dan mengajar. Berdasarkan pendapat di atas, dapat dikembangkan beberapa pemahaman tentang posisi media serta peran dan kontribusinya dalam kegiatan pembelajaran.

Beberapa pemahaman itu antara lain: (1) media merupakan wadah dari pesan yang oleh sumber pesan ataupun penyalurnya ingin diteruskan kepada sasaran atau penerima pesan tersebut. (2) aplikasi media pembelajaran berpijak pada kaidah ilmu komunikasi, antara lain dikatakan oleh Lasswell (1982) dalam Asra, Deni Darmawan \& Cepi Riana (2007) "who says what in which channels to whom in what effect". Secara rinci dapat diuraikan sebagai berikut:

1. Who, siapa yang menyatakan? (dosen, pengajar, widyaiswara, instruktur, fasilitator, dan semua yang berfungsi sebagai pengirim pesan).

2. What, pesan atau ide/gagasan apa yang disampaikan

3. Which Channels, dengan saluran apa, media saluran apa, media atau sarana apa, pesan itu ingin disampaikan.

4. To Whom, kepada siapa (sasaran, mahasiswa/peserta didik)

5. What effect, hasil atau dampak yang akan didapat setelah pembelajaran.

Unsur-unsur di tersebut di atas, tampaknya menjadi target (goal) dari suatu kegiatan pembelajaran adalah dampak atau hasil yang ingin dicapai dalam kegiatan pembelajaran. Dalam kajian kependidikan, istilah itu dikenal dengan nama "meaningful learning experience", yaitu suatu pengalaman belajar yang bermakna sebagai hasil dari suatu kegiatan pembelajaran (instruction). Terjadinya belajar bermakna ini tidak terlepas dari peran media terutama dari kedudukan dan fungsinya. Secara umum media mempunyai kegunaan:

1. Memperjelas pesan agar tidak terlalu verbalistis.

2. Mengatasi keterbatasan ruang, waktu tenaga dan daya indra.

3. Menimbulkan gairah belajar, interaksi lebih langsung antara murid dengan sumber belajar.

4. Memungkinkan anak belajar mandiri sesuai dengan bakat dan kemampuan visual, auditori \& kinestetiknya.

6. Memberi rangsangan yang sama, mempersamakan pengalaman \& menimbulkan persepsi yang sama.

Secara umum media bercirikan tiga unsur pokok, yaitu: suara, visual, dan gerak. Lebih rinci Anderson (1997) dalam Asra, Deni Darmawan \& Cepi Riana (2007) mengelompokan media berikut ini:

1. Media visual: yaitu media yang hanya dapat dilihat, yang termasuk kelompok visual, seperti foto, gambar, poster, grafik, kartun, liflet, buklet, torso, film bisu, model 3 dimensi seperti diorama dan mokeup. 
2. Media Audio: adalah media yang hanya dapat didengar saja, seperti kaset audio, radio, MP3 Player, iPod.

3. Media Audio Visual: yaitu media yang dapat dilihat sekaligus dapat didengar, seperti film bersuara, video, televisi, sound slide.

4. Multimedia : adalah media yang dapat menyajikan unsur media secara lengkap seperti suara, animasi, video, grafis dan film. Multimedia sering diidentikan dengan komputer, internet dan pembelajaran berbasis komputer (CBI).

5. Media Realia: yaitu semua media nyata yang ada di lingkungan alam, baik digunakan dalam keadaan hidup maupun sudah diawetkan, seperti tumbuhan, batuan, binatang, insektarium, herbarium, air, sawah dan sebagainya.

Pengembangan media dalam suatu konsepsi teknologi pembelajaran harus memiliki ciri: (a) berorientasi pada sasaran (target oriented), (b) menerapkan konsep pendekatan sistem, dan (c) memanfaatkan sumber belajar yang bervariasi. Sehingga aplikasi media dan teknologi pendidikan, bisa merealisasikan suatu konsep "teaching less learning more". Artinya secara fisik bisa saja kegiatan pengajar di kelas dikurangi, karena ada sebagian tugas pengajar yang didelegasikan pada media, namun tetap mendorong tercapainya hasil belajar peserta didik (Asra, Deni Darmawan \& Cepi Riana, 2007)

\section{Macromedia Flash 8}

\section{Pengertian Macromedia Flash 8}

Macromedia Flash 8 merupakan salah satu Authoring tool yang dapat digunakan untuk mengembangkan aplikasi multimedia. Macromedia flash 8 memiliki fitur yang menyediakan keperluan untuk membuat animasi dan menyajikan animasi yang dinamis dan komunikatif. Dengan macromedia flash 8 dapat ditampilkan suatu animasi yang dapat menarik minat mahasiswa/peserta didik dalam mengikuti proses kegiatan belajar mengajar (Ariesto H.S, 2008).

\section{Konsep Dasar Animasi Flash 8}

Animasi menggambarkan obyek yang bergerak agar kelihatan hidup. Membuat animasi berarti menggerakkan gambar seperti kartun, lukisan, tulisan dan lain-lain. Animasi mulai dikenal sejak media televisi mulai menyajikan gambar-gambar bergerak yang berasal dari rekaman kamera maupun hasil karya seorang animator. Animasi sangat baik untuk presentasi, pemodelan, dokumentasi dan lain-lain. Film-film animasi kartun dari Walt Disney yang telah terkenal di dunia beberapa tahun yang lalu, masih tetap disukai orang sampai saat ini (Ariesto H.S, 2008).

\section{Teknik pembuatan animasi Flash 8}

Teknik pengerjaan animasi pun telah berubah seiring dengan perkembangan teknologi komputer. Dahulu pembuatan animasi dilakukan dengan membuat gambar-gambar yang digabungkan sehingga merupakan gambar yang bergerak. Untuk membuat satu durasi animasi memerlukan jumlah gambar (frame) yang cukup banyak. Jumlah frame tiap detik (frame per second/fps) merupakan satuan yang akan menghasilkan kualitas animasi. Makin banyak frame per detik, makin baik kualitas animasi yang dihasilkannya. Efisiensi pengerjaan pembuatan animasi telah dilakukan sejak diperkenalkannya teknik animasi cell (celluloid sheet, semacam kertas transparan).

Gagasan dasar dari cell adalah satu gambar dibuat untuk satu frame. Perubahan kecil dibuat dalam frame-frame berikutnya, sampai perubahan yang berarti merupakan keyframe. Animasi yang dibentuk oleh frame-frame antara dua keyframe disebut in-between animation, biasanya dibuat oleh seorang 
animator tesendiri. Teknik animasi cell menjadi dasar pembuatan semua animasi. Dengan komputer, yang perlu ditentukan adalah keyframe, sedangkan frame-frame di antaranya akan diselesaikan oleh komputer (Ariesto H.S, 2008).

\section{Animasi dalam Flash 8}

Multimedia terdiri dari dua kategori, yaitu linier dan non linier (interaktif). Movie non linier dapat berinteraksi dengan aplikasi web yang lain melalui penekanan sebuah tombol navigasi, pengisian form dan lain-lain. Desainer Web membuat movie non linier dengan membuat tombol navigasi, animasi logo, animasi form dengan sinkronisasi suara. Flash movie adalah grafik dan animasi untuk situs web yang merupakan grafik vektor dengan ukuran file kecil, sehingga dapat di-load dalam waktu singkat. Pada dasarnya animasi terdiri dari grafik vektor, tetapi dapat juga dilengkapi dengan bitmap dan suara. Flash movie dapat dijalankan dengan Flash Player melalui browser atau pada aplikasi stand alone. Flash dapat digunakan untuk membuat animasi interaktif, di mana pengunjung dapat memasukkan data, kemudian Flash mengevaluasi dan menampilkan hasilnya (Ariesto H.S, 2008).

\section{Tools pada Flash 8}

Sebelum mulai mempelajari Flash, perlu mengetahui beberapa istilah yang biasa digunakan dalam Flash, serta bagaimana cara menggunakannya. Toolbox berisi alat-alat kerja dengan icon untuk masingmasing fungsi. Toolbox terdiri dari empat bagian, yaitu tools, view, color dan options.

TOOLS berisi fungsi-fungsi untuk menggambar, memilih, membuat teks, mewarnai, menghapus, dan membuat path. Tools terdiri dari beberapa icon untuk menggambar, yaitu:

- Pencil Tool $\rightarrow$ digunakan untuk menggambar seperti fungsi pencil

- Pen Tool $\rightarrow$ untuk menggambar part seperti garis lurus dan garis lengkung

- Line Tool $\rightarrow$ untuk menggambar garis lurus

- Oval Tool $\rightarrow$ untuk menggambar lingkaran dan elips

- Rectangle Tool $\rightarrow$ untuk menggambar kotak

- Brush Tool $\rightarrow$ untuk menggambar menggunakan brush

VIEW berisi fungsi-fungsi untuk menampilkan gambar

- Zoom Tool $\rightarrow$ untuk memperbesar dan memperkecil gambar

- Hand Tool $\rightarrow$ untuk menggeser gambar

COLORS berisi fungsi-fungsi untuk mewarnai

- Stroke Color $\rightarrow$ untuk menentukan warna outline pada gambar

- Fill Color $\rightarrow$ untuk mewarnai gambar.

OPTIONS berisi pilihan lain untuk membuat variasi pada fungsi-fungsi tool dan view. Bila Eraser tool diklik, akan muncul Eraser mode, Faucet dan Eraser Shape, dengan banyak pilihan sebagai berikut ini, 


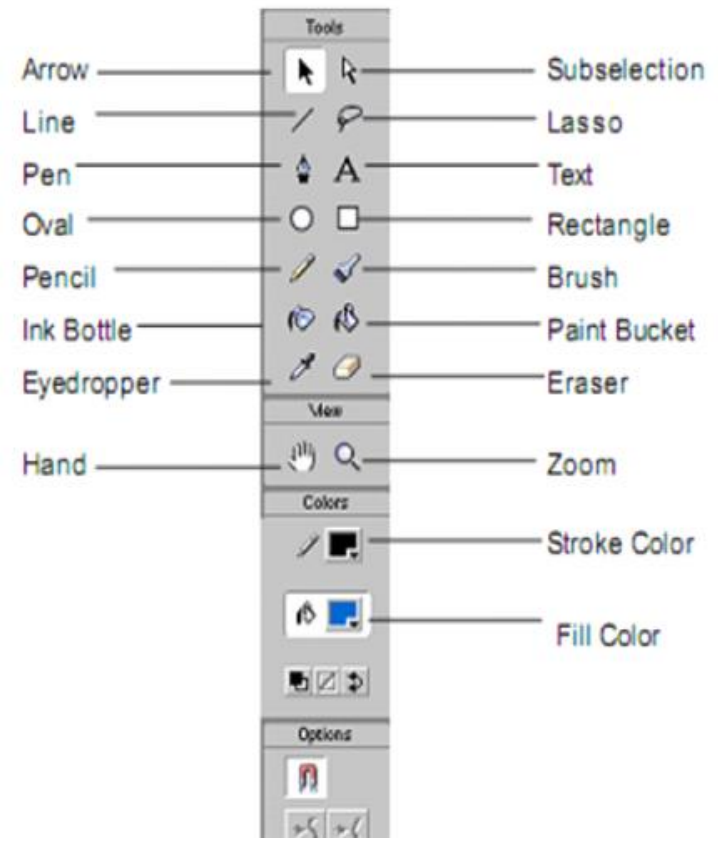

\section{Matematika dan Pembelajaran Matematika}

Istilah Matematika berasal dari bahasa Yunani, mathein atau manthenien yang artinya mempelajari. Kata matematika diduga erat hubungannya dengan kata Sangsekerta, medha atau widya yang artinya kepandaian, ketahuan atau intelegensia (Sri Subariah, 2006:1). Menurut Ruseffendi (1993), matematika adalah terjemahan dari Mathematics. Matematika itu terorganisasikan dari unsur-unsur yang tidak didefinisikan, definisi-definisi, aksioma-aksioma dan dalil-dalil yang dibuktikan kebenarannya, sehingga matematika disebut ilmu deduktif.

Dengan demikian dapat dikatakan bahwa matematika merupakan ilmu pengetahuan yang mempelajari struktur yang abstrak dan pola hubungan yang ada di dalamnya. Ini berarti bahwa belajar matematika pada hakekatnya adalah belajar konsep, struktur konsep dan mencari hubungan antar konsep dan strukturnya.

Menurut Ruseffendi agar peserta didik memahami dan mengerti konsep matematika seyogyanya diajarkan dengan urutan konsep murni, dilanjutkan dengan konsep notasi, dan diakhiri dengan konsep terapan. Untuk dapat mempelajari struktur matematika dengan baik maka representasinya dimulai dengan benda-benda konkrit yang beraneka ragam. Misalnya anak akan lebih cepat memahami arti benda-benda bila disajikan berbagai bentuk dan jenis benda-benda atau dengan kata lain bahwa benda-benda yang akan diamati harus beragam jenisnya. Langkah-langkah yang dapat dilakukan oleh pengajar matematika dalam pembelajaran Matematika adalah sebagai berikut:

a. Mengenalkan dengan konsep Matematika melalui benda-benda konkrit.

b. Menambah dan memperkaya pengalaman peserta didik.

c. Menanamkan konsep melalui jenis permainan.

d. Menelaah sifat bersama atau membeda-bedakan jenis dan macam konsep matematika.

e. Menerapkan dengan bentuk simbol-simbol.

f. Menerapkan konsep-konsep (struktur) Matematika secara formal sehingga sampai pada aksioma dan dalil berdasarkan pengalaman peserta didik. 
Pengajar dalam melaksanakan pembelajaran matematika diharapkan mampu mendasari dengan pendekatan-pendekatan pembelajaran yang tepat, antara lain :

a. Peserta didik harus menggunakan benda-benda konrit dan membuat abstraksinya dari konsep-konsep.

b. Materi yang akan diajarkan harus ada hubungannya atau berkaitan dengan yang sudah dipelajari.

c. Mengubah suasana abstrak ke dalam suasana konkrit menggunakan simbol.

d. Matematika adalah ilmu kreatif oleh karena itu harus diajarkan dengan ilmu seni.

Jadi pembelajaran matematika adalah pembelajaran yang dapat menata kemampuan berpikir para peserta didik, bernalar, memecahkan masalah, berkomunikasi, mengaitkan materi matematika dengan keadaan sesungguhnya

\section{METODE PENELITIAN}

\section{Jenis Penelitian dan Prosedur Pelaksanaan Penelitian}

Penelitian ini merupakan penelitian pengembangan dengan model pengembangan mengadopsi model Borg and Gall dan Dick \& Carey. Target dari penelitian ini adalah menghasilkan bahan ajar elektronik berbasis multimedia menggunakan Macromedia Flash 8 untuk mata kuliah Konsep Dasar Matematika mahasiswa materi Sistem Persamaan Linear.

Prosedur pengembangan dalam penelitian ini diadaptasi dari model pengembangan Borg and Gall dan Dick \& Carey yang dimodifikasi. Terdapat 10 tahapan model pengembangan menurut Borg and Gall dan Dick \& Carey (2005), yaitu:

\section{1) Identify instructional goal}

Pada tahapan ini dilakukan identifikasi tentang apa yang akan didapatkan (hasil akhir yang akan dicapai) oleh peserta didik setelah mengikuti proses pembelajaran.

2) Conduct Instructional analysis

Tahapan ini proses yang dilakukan adalah melakukan analisis tentang kegiatan belajar peserta didik atau langkah-langkah apa yang akan peserta didik lakukan untuk mencapai tujuan dalam suatu pembelajaran.

3) Analyze learners and contexts

Tahapan ini kegiatan yang dilakukan adalah melakukan analisis tentang karakter peserta didik dan dimana mereka akan melakukan kegiatan pembelajaran sehingga sesuai dengan kondisi, karakter dan tempat yang cocok untuk proses pembelajaran.

4) Write performance objectives

Tahapan ini kegiatan mulai spesifik yaitu menentukan tujuan pembelajaran yang akan dicapai berdasarkan analisis kebutuhan dan karakteristik peserta didik.

5) Develop assessment instruments

Pada tahapan ini kegiatan yang dilakukan adalah membuat instrumen penilaian untuk mengukur kemampuan peserta didik.

6) Develop instructional strategy

Pada tahap ini kegiatan yang dilakukan adalah membuat strategi pembelajaran untuk mencapai tujuan pembelajaran.

7) Develop and select instructional materials

Pada tahap ini kegiatan yang dilakukan adalah memilih dan mengembangkan bahan pembelajaran yang disesuaikan dengan tujuan yang akan dicapai. 
8) Design and conduct formative evaluation of instruction

Pada tahap ini dilakukan kegiatan merancang kegiatan uji coba atau evaluasi produk dalam sebuah pembelajaran yang dilakukan dalam tiga tahapan yaitu:

a) One to one evaluation (3-4 orang)

b) Small group evaluation (8-20 orang)

c) Field trial evaluation (1 kelas)

9) Revise Instruction

Tahap ini merupakah tindak lanjut dari kegiatan uji coba atau evaluasi dari kegiatan 8 yaitu melakukan perbaikan atau merevisi produk yang telah dibuat.

10) Design and conduct summative evaluation

Tahapan terakhir dari proses pengembangan yang dilakukan adalah membuat dan melakukan evaluasi terhadap hasil pembelajaran yang disesuaikan dengan tujuan yang akan dicapai.

Dalam penelitian ini, peneliti merangkum dan memodifikasi model pengembangan di atas ke dalam empat tahap yaitu: (1) tahap pendefinisian kebutuhan, (2) tahap desain produk, (3) tahap pengembangan dan evaluasi, (4) tahap desiminasi produk akhir.

Berikut akan dipaparkan bagaimana prosedur pengembangan yang digunakan dalam penelitian pengembangan ini.

1. Tahap Pendefinisian Kebutuhan

Pada tahap ini peneliti melakukan observasi di kelas berkaitan dengan proses belajar mengajar yang dilakukan, apa yang dibutuhkan oleh mahasiswa pada saat mereka belajar konsep dasar matematika. Tahap ini juga digunakan untuk melihat bahan ajar yang digunakan Dosen pada saat pembelajaran terkait dengan pemanfaatan Flexible Learning sebagai sarana pembelajaran berbasis ICT yang dilakukan di Universitas Kristen Satya Wacana.

2. Tahap Desain Produk

Tahap ini akan di rancang dan dibuat produk berupa bahan ajar elektronik berbasis multimedia menggunakan Macromedia Flash 8 untuk mata kuliah Konsep Dasar Matematika. Langkah-langkah yang dilakukan untuk mendesain produk bisa dilihat pada tahapan berikut ini.

a) Mengkaji kurikulum matakuliah Konsep Dasar Matematika untuk melihat Standar Kompetensi dan Kompetensi Dasar mata kuliah

b) Mengkaji teori belajar yang sesuai dengan materi dan karakteristik mahasiswa

c) Melihat materi yang akan dikembangkan yaitu sistem persamaan linear 3 varibel untuk menentukan agihan waktu dan urutan pemberian materi.

d) Membuat Story Board urutan materi yang ditampilkan dan bentuk animasi yang akan dimunculkan

e) Merancang kebutuhan teks, gambar, audio, dan video yang akan digunakan di animasi flash.

f) Menentukan tampilan dan banyak scine yang akan dikembangkan di flash

3. Tahap Pengembangan dan Evaluasi

Pada tahap ini peneliti akan melakukan proses pengembangan produk sesuai dengan apa yang telah direncanakan dalam desain produk. Desain produk yang telah dibuat dan dikembangkan akan dievaluasi terlebih dahulu oleh para ahli atau pakar dalam bidang media dan pengembangan bahan ajar untuk mendapatkan validitas produk.

Bahan ajar yang dikembangkan kemudian divalidasi oleh pakar (expertjudgment). Validasi ini dilakukan oleh ahli atau pakar (expert judgment) di bidang media pembelajaran dan pengembangan bahan ajar. 
Uji coba produk dilakukan pada sekelompok mahasiswa dengan prosedur one to one, small group evaluation, dan field trial evaluation pada mahasiswa yang menjadi subjek penelitian. Dick \& Carey (2005) merekomendasikan one to one yaitu berjumlah 3 sampai 4 orang, small group evaluation yaitu berjumlah 8 sampai 20 orang dan field trial evaluation yaitu berjumlah 1 kelas. Selanjutnya akan dilakukan evaluasi dan revisi terhadap produk bahan ajar elektronik yang telah diujicobakan dengan tujuan menyempurnakan produk.

4. TahapAkhir

Pada tahap akhir ini dihasilkan bahan ajar matematika elektronik berbasis multimedia dengan macromedia flash 8.0 yang telah lolos dari uji coba, yang nantinya dapat digunakan oleh dosen dalam mengajar di kelas.

\section{Subjek Uji Coba}

Subjek uji coba dalam penelitian dan pengembangan ini adalah mahasiswa S1 PGSD kelas G 2009 untuk uji coba one to one evaluation berjumlah 3 sampai 4 orang, small group evaluation berjumlah 8 orang dan kelas A mahasiswa 2010 untuk uji coba field trial evaluation untuk 1 kelas.

\section{Jenis Data}

Jenis data yang diperoleh dalam penelitian dan pengembangan ini berupa data kualitatif yang berasal dari hasil validasi pakar, angket dari mahasiswa hasil uji coba, hasil observasi pembelajaran serta hasil angket respon mahasiswa terhadap pembelajaran yang dilakukan.

\section{Instrumen Pengumpulan Data}

Instrumen yang digunakan dalam penelitian ini adalah lembar validasi pakar, dan angket tertutup tentang respon mahasiswa setelah menggunakan bahan ajar matematika elektronik, dan lembar observasi untuk melihat proses uji coba dalam pembelajaran. Instrumen validasi pakar meliputi dua aspek yaitu aspek materi dan media. Berikut adalah indikator untuk menentukan kelayakan dari bahan ajar yang dikembangkan.

Tabel 1 Indikotar penilaian aspek materi dan media

\begin{tabular}{|c|c|c|}
\hline No. & Indikator Materi & Indikator Media \\
\hline 1. & Materi yang disajikan ada dalam kurikulum S1 PGSD & Program menggunakan komposisi warna menarik \\
\hline 2. & $\begin{array}{l}\text { Materi yang ditampilkan sesuai dengan materi } \\
\text { kurikulum S1 PGSD }\end{array}$ & Tampilan awal saat program aktif terlihat menarik \\
\hline 3. & $\begin{array}{l}\text { Materi yang ditampilkan mampu memperjelas isi materi } \\
\text { yang ditayangkan }\end{array}$ & Text dalam tampilan utama dan menu utama jelas \\
\hline 4. & $\begin{array}{l}\text { Animasi yang ditampilkan mampu memperjelas isi materi } \\
\text { yang ditayangkan }\end{array}$ & $\begin{array}{l}\text { Menu yang ditampilkan dapat digunakan dengan } \\
\text { mudah }\end{array}$ \\
\hline 5. & $\begin{array}{l}\text { Animasi yang ditampilkan mempermudah Anda } \\
\text { memahami materi }\end{array}$ & Tombol navigasi dapat berfungsi dengan baik \\
\hline 6. & $\begin{array}{l}\text { Animasi yang ditampilkan menarik dan sesuai dengan } \\
\text { materi yang disajikan }\end{array}$ & Output sesuai pilihan \\
\hline 7. & $\begin{array}{l}\text { Bahan ajar ini memudahkan Anda untuk belajar sistem } \\
\text { persamaan linear tiga variabel }\end{array}$ & Menu program dapat digunakan dengan baik \\
\hline 8. & $\begin{array}{l}\text { Soal-soal yang ditampilkan dalam latihan sudah sesuai } \\
\text { dengan materi dan memenuhi tujuan pembelajaran? }\end{array}$ & $\begin{array}{l}\text { Informasi yang disajikan program } \\
\text { berurutan }\end{array}$ \\
\hline 9. & $\begin{array}{l}\text { Bahan ajar ini dapat dijadikan alat bantu belajar } \\
\text { mandiri }\end{array}$ & Isi materi mudah dibaca \\
\hline 10. & $\begin{array}{l}\text { Bahan ajar ini membuat Anda termotivasi untuk } \\
\text { belajar secara mandiri }\end{array}$ & Isi materi mudah dipahami \\
\hline 11 & & $\begin{array}{l}\text { Animasi pada bahasan materi sudah sesuai dengan } \\
\text { acuan dasar teori yang ada }\end{array}$ \\
\hline
\end{tabular}


Tabel 2 Indikotar pelaksanaan pembelajaran

\begin{tabular}{|c|c|c|}
\hline NO & $\begin{array}{l}\text { KEGIATAN } \\
\text { PEMBELAJARAN }\end{array}$ & KEGIATAN PEMBELAJARAN \\
\hline \multirow{3}{*}{1} & & $\begin{array}{l}\text { Memberikan penjelasan tentang kegiatan pembelajaran yang akan } \\
\text { dilaksanakan yaitu menggunakan sarana Flexible- Learning dan Bahan } \\
\text { Ajar Elektronik Berbasis Multimedia }\end{array}$ \\
\hline & KEGIATAN AWAL & $\begin{array}{l}\text { Menjelaskan tujuan pembelajaran yang akan dicapai untuk memberikan } \\
\text { motivasi kepada mahasiswa dan pedoman penggunaan bahan ajar } \\
\text { elektronik yang telah disiapkan }\end{array}$ \\
\hline & & $\begin{array}{l}\text { Memberikan rumusan masalah pada tampilan awal di Flexible-Learning } \\
\text { sebagai acuan kegiatan dan fokus dari materi yang akan dipelajari }\end{array}$ \\
\hline \multirow{4}{*}{2} & \multirow{4}{*}{ KEGIATAN INTI } & $\begin{array}{l}\text { Dosen mengarahkan peserta didik untuk membuka bahan ajar elektronik } \\
\text { yang sudah disiapkan di Flexible-Learning }\end{array}$ \\
\hline & & Dosen mengarahkan mahasiswa untuk melaksanakan eksplorasi \\
\hline & & $\begin{array}{l}\text { Dosen dan mahasiswa melaksanakan tanya jawab terkait dengan hasil } \\
\text { eksplorasi yang dilSayakan oleh mahasiswa }\end{array}$ \\
\hline & & $\begin{array}{l}\text { Dosen bersama mahasiswa membahas materi yang telah diberikan } \\
\text { berdasarkan hasil eksplorasi dan diskusi bersama }\end{array}$ \\
\hline \multirow{3}{*}{3} & \multirow{3}{*}{ PENUTUP } & $\begin{array}{l}\text { Dosen bersama mahasiswa menyimpulkan pembelajaran yang telah } \\
\text { dilaksanakan }\end{array}$ \\
\hline & & $\begin{array}{l}\text { Mahasiswa mengerjakan evaluasi yang telah disediakan dalam bahan ajar } \\
\text { elektronik }\end{array}$ \\
\hline & & $\begin{array}{l}\text { Dosen menyampaikan rencana kegiatan yang akan dilaksanakan pada } \\
\text { pertemuan berikutnya }\end{array}$ \\
\hline
\end{tabular}

\section{Teknik Analisis Data}

Analisa data untuk bahan ajar elektronik yang dibuat melalui validasi dan uji coba dengan menghitung skor yang diperoleh untuk menilai kualitas produk berupa bahan ajar Berbasis multimedia yang dikembangkan. Data yang terkumpul dalam penelitian ini berupa data kuantitatif yaitu skor dengan skala 1-5 (skor 1 untuk sangat kurang, skor 2 untuk kurang, skor 3 untuk cukup, skor 4 untuk baik, dan skor 5 untuk sangat baik) dan data kualitatif berkaitan dengan data penilaian mahasiswa terkait dengan pemanfaatan bahan ajar elektronik, kelebihan dan kekurangan bahan ajar. Skor data kualitatif dikonversi menjadi data kuantitatif menggunakan acuan konversi seperti pada tabel 3 yang menggunakan Skala Likert (Suharsimi Arikunto, 2005). Hasil dari data penelitian ini digunakan untuk memperbaiki produk Bahan ajar matematika elektronik. 
Tabel 3 Tabel Acuan Konversi Data Kualitatif ke dalam Data Kuantitatif

\begin{tabular}{lll}
\hline \multicolumn{1}{c}{ Rumus Perhitungan } & \multicolumn{1}{c}{ Perhitungan } & \multicolumn{1}{c}{$\begin{array}{c}\text { Inter- } \\
\text { prestasi }\end{array}$} \\
\hline $\bar{x}>M_{i}+1,8 S D_{i}$ & $\bar{x}>4,20$ & $\begin{array}{l}\text { Sangat } \\
\text { baik }\end{array}$ \\
$M_{i}+0,6 S D_{i}<\bar{x} \leq M_{i}+1,8 S D_{i}$ & $3,40<\bar{x} \leq 4,20$ & Baik \\
$M_{i}-0,6 S D_{i}<\bar{x} \leq M_{i}+0,6 S D_{i}$ & $2,60<\bar{x} \leq 3,40$ & Cukup \\
$M_{i}-1,8 S D_{i}<\bar{x} \leq M_{i}-0,6 S D_{i}$ & $1,80<\bar{x} \leq 2,60$ & Kurang \\
$\bar{x} \leq M_{i}-1,8 S D_{i}$ & $\bar{x} \leq 1,80$ & Sangat \\
\hline
\end{tabular}

Keterangan:

$$
\begin{aligned}
\mathrm{Mi} & =\text { rerata ideal } \\
& =1 / 2(\text { skor maksimal ideal }+ \text { skor minimal ideal }) \\
& =\text { Standar deviasi ideal } \\
& =1 / 6(\text { skor maksimal ideal }- \text { skor minimal ideal }) \\
\bar{x} & =\text { skor rerata data empiris }
\end{aligned}
$$

\section{Indikator Keberhasilkan Pengembangan Bahan Ajar}

Pengembangan bahan ajar ini dikatakan berhasil jika dari segi materi dan media memiliki kategori BAIK sesuai aspek yang telah diuraikan dalam tabel 1 .

\section{HASIL PENELITIAN DAN PEMBAHASAN}

\begin{tabular}{|c|c|c|}
\hline No & Kegiatan & Hasil \\
\hline 1 & $\begin{array}{l}\text { Anilisis } \\
\text { Kebutuhan }\end{array}$ & $\begin{array}{l}\text { 1. Didapatkan bahwa dalam pembelajaran } \\
\text { berbasis E-learning masih digunakan } \\
\text { bahan ajar yang berbasis teks } \\
\text { 2. Mahasiswa merasa bosan dan jenuh } \\
\text { menggunakan bahan ajar teks } \\
\text { 3. Memerlukan bahan ajar dalam bentuk } \\
\text { yang lain }\end{array}$ \\
\hline 2 & $\begin{array}{l}\text { Desain Produk } \\
\text { (Desain } \\
\text { Pengembangan } \\
\text { Bahan Ajar) }\end{array}$ & $\begin{array}{l}\text { Hasil Desain produk dihasilkan: } \\
\text { 1. Story Board urutan materi yang } \\
\text { ditampilkan dan bentuk animasi yang } \\
\text { akan dimunculkan } \\
\text { 2. Video pendukung bahan ajar } \\
\text { 3. Gambar pendukung bahan ajar } \\
\text { 4. Musik pendukung bahan ajar }\end{array}$ \\
\hline 3 & $\begin{array}{l}\text { Pengembangan } \\
\text { dan Evaluasi }\end{array}$ & $\begin{array}{l}\text { Pengembangan bahan ajar dilakukan } \\
\text { dengan menggunakan software macromedia } \\
\text { Flash } 8 \text { dengan nama bahan ajar elektronik. } \\
\text { Dibuat dalam empat (4) sciene dengan } \\
\text { minimal setiap sciene terdiri dari } 5 \text { layer. } \\
\text { Bahan ajar yang sudah dibuat dilakukan uji } \\
\text { pakar dan uji coba kepada mahasiswa. }\end{array}$ \\
\hline 4 & Tahap Akhir & $\begin{array}{l}\text { Hasil validasi dari pakar didapatkan kriteria } \\
\text { bahan ajar dengan kategori Bagus dan siap } \\
\text { digunakan dengan melalukan revisi terlebih } \\
\text { dahulu. }\end{array}$ \\
\hline
\end{tabular}

Proses pengembangan bahan ajar yang akan digunakan dalam pembelajaran matematika tentang sistem persamaan linear tiga variabel melalui tahapan-tahapan seperti terlihat dalam tabel 4 berikut:

Tabel 4 Proses pengembangan bahar ajar elektronik multimedia dengan macro media flash 8 
Berikut adalah contoh tampilan bahan ajar elektronik berbasis multimedia yang telah dikembangkan dan urutan penggunaannya.

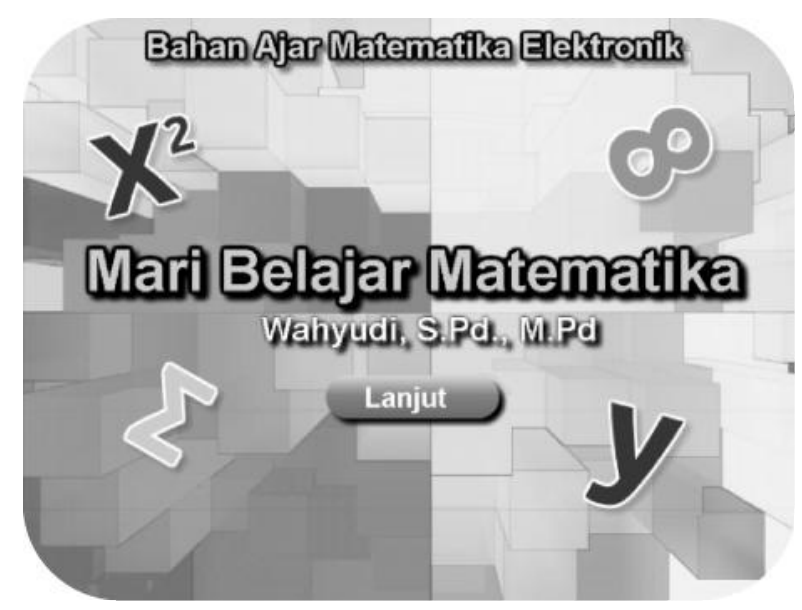

Gambar 1. Tampilan awal bahan ajar elektronik

Untuk masuk ke dalam materi dalam bahan ajar maka ditekan tombol "Lanjut" maka aka muncul tampilan berikut ini.

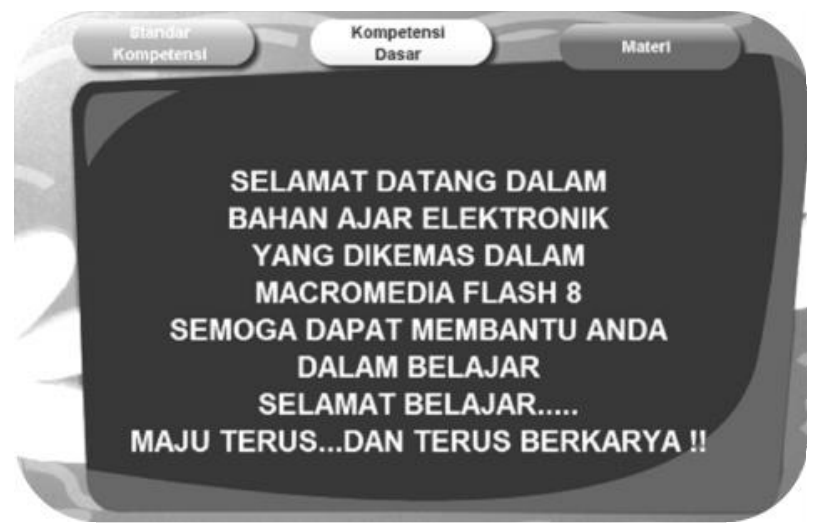

Gambar 2. Tampilan menu utama bahan ajar elektronik

Melalui menu utama ini, mahasiswa dapat melihat standar kompetensi, kompetensi dasar dan materi apa saja yang ditampilkan dalam bahan ajar ini. Untuk melihat masing-masing menu maka yang dilakukan adalah menekan tombol yang sudah tersedia. Misalkan untuk melihat materi yang tersedia, maka yang dilakukan adalah menekan tombol "materi" maka akan muncul tampilan seperti berikut ini. 


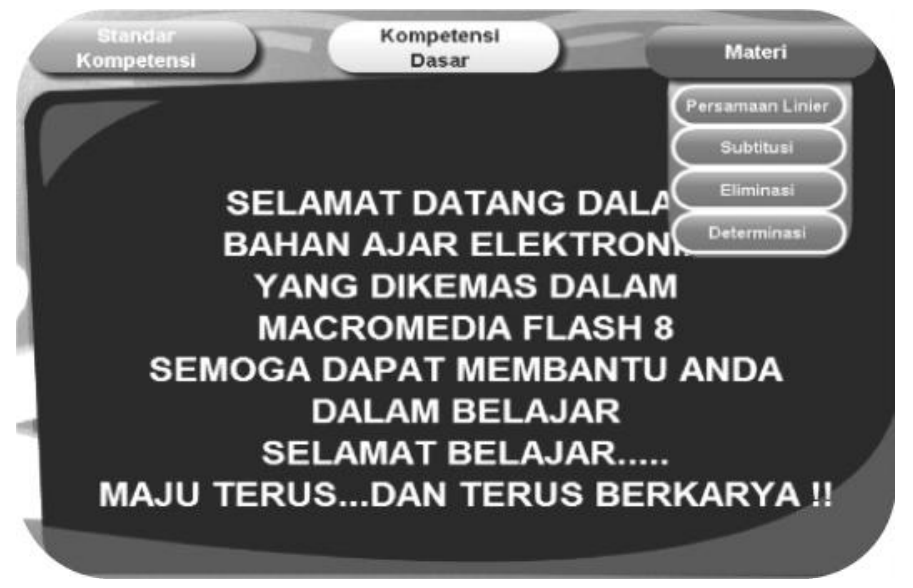

Gambar 3. Tampilan menu utama untuk materi

Berdasarkan gambar 3 di atas tersedia empat materi yang yaitu: persamaan linear, eliminasi, subtitusi, dan determinasi. Untuk dapat mengakses materi tinggal memilih materi yang tersedia. Materimateri yang tersedia dilengkapi dengan teks, gambar, audio, dan video serta latihan soal yang sudah disediakan. Berikut salah satu tampilan video yang digunakan sebagai pengantar materi.

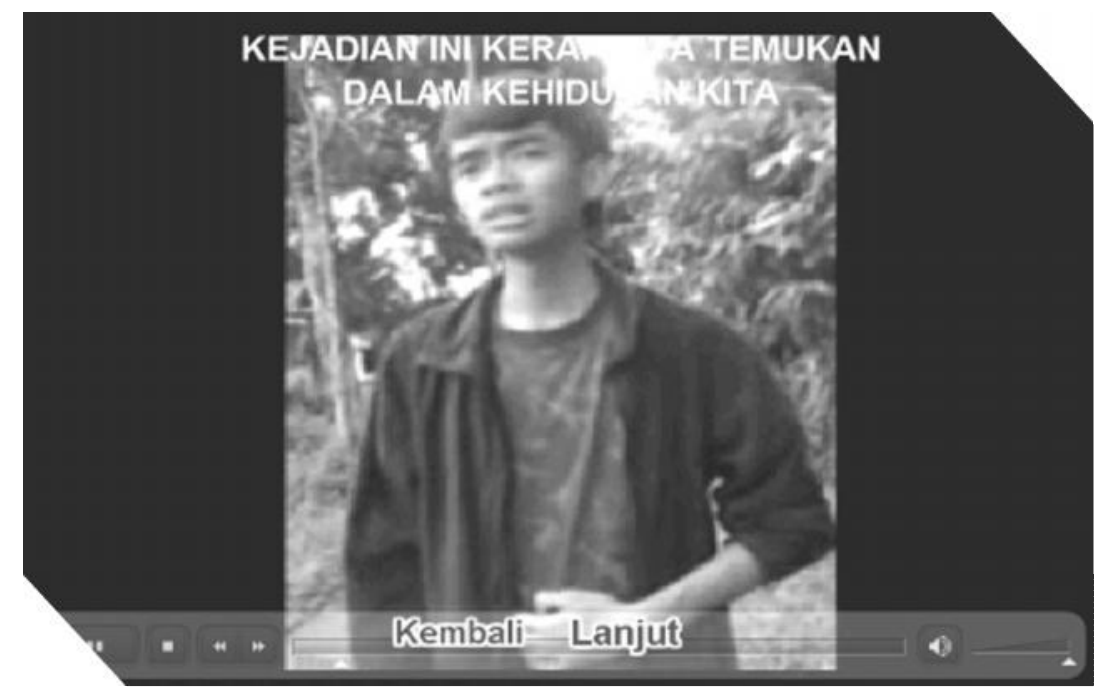

Gambar 4. Contoh video dalam materi

Setelah proses pengembangan bahan ajar selesai maka dilakukan uji pakar (ada dua pakar yaitu pakar media dan pakar materi matematika) dan uji coba untuk melihat kualitas bahan ajar yang telah dibuat. Hasil uji pakar (media dan materi) dan uji coba yang dilakukan dapat dilihat pada Tabel 5 dan 6 berikut ini. 
Tabel 5 Rekap hasil evaluasi terhadap bahan ajar oleh pakar

\begin{tabular}{ccc}
\hline Aspek & Nilai & Kategori \\
\hline Materi & 3.7 & BAIK \\
Media & 4.18 & BAIK \\
\hline
\end{tabular}

Tabel 6 Rekap Hasil Evaluasi Terhadap Bahan Ajar Oleh Mahasiswa

\begin{tabular}{ccccc}
\hline \multicolumn{1}{c}{ No } & Jenis Uji Coba & Nilai & Rata-rata & Kategori \\
\cline { 1 - 1 } Aspek Materi & & 4.13 & & \\
\hline $1 \quad$ One-To-One Evaluation & 4.05 & 3.98 & BAIK \\
$2 \quad$ Small Group Evaluation & 3.75 & & \\
$3 \quad$ Field Group Evaluation & & & \\
\hline Aspek Media & 4.04 & & BAIK \\
$1 \quad$ One-To-One Evaluation & 4.51 & 4.14 & \\
$2 \quad$ Small Group Evaluation & 3.88 & & \\
$3 \quad$ Field Group Evaluation & &
\end{tabular}

Hasil ini menunjukkan bahwa bahan ajar elektronik multimedia yang dikembangkan memiliki kategori baik dari segi materi dan media sehingga dapat digunakan dalam pembelajaran. Kategori baik yang didapat menunjukkan bahwa aspek materi yang dikembangkan ada dan sesuai dengan materi dalam kurikulum S1 PGSD, tampilan materi yang ada memudahkan untuk dipahami, animasi, gambar dan video menambah daya tarik dan memudahkan materi untuk dipelajari, materi yang dikembangkan membuat mahasiswa lebih mudah belajar mandiri. Untuk aspek media dalam kategori baik menunjukkan bahwa tampilan baik warna, teks, gambar, anamasi memberikan daya tarik untuk dipelajari, penggunaan tombol mudah digunakan dan outputnya sesuai, urutan materi tersusun sistematis sehingga mudah dipelajari, isi materi mudah dibaca dan dipahami dan sesuai materi yang diharapkan.

Hasil evaluasi rancangan pembelajaran yang dilakukan diperoleh hasil berikut ini. 
Tabel 7 Rekap hasil evaluasi terhadap terhadap pembelajaran

\begin{tabular}{|c|c|c|c|}
\hline No. & Indikator & Nilai & Kategori \\
\hline 1. & $\begin{array}{l}\text { Ketepatan standar kompetensi } \\
\text { dengan kurikulum }\end{array}$ & 5 & $\begin{array}{l}\text { SANGAT } \\
\text { BAGUS }\end{array}$ \\
\hline 2. & $\begin{array}{l}\text { Ketepatan kompetensi dasar dengan } \\
\text { kurikulum }\end{array}$ & 4 & BAGUS \\
\hline 3. & $\begin{array}{l}\text { Ketepatan indikator dengan } \\
\text { kurikulum }\end{array}$ & 4 & BAGUS \\
\hline 4. & $\begin{array}{l}\text { Ketepatan media/sumber } \\
\text { pembelajaran dengan materi }\end{array}$ & 4 & BAGUS \\
\hline 5. & $\begin{array}{l}\text { Ketepatan urutan materi } \\
\text { pembelajaran berdasarkan model } \\
\text { pembelajaran yang dikembangkan }\end{array}$ & 4 & BAGUS \\
\hline 6. & $\begin{array}{l}\text { Kemudahan petunjuk penggunaan } \\
\text { bahan ajar dalam pembelajaran }\end{array}$ & 3 & SEDANG \\
\hline 7. & $\begin{array}{l}\text { Kemudahan langkah-langkah } \\
\text { pembelajaran dengan menggunakan } \\
\text { bahan ajar yang digunakan }\end{array}$ & 4 & BAGUS \\
\hline 8. & $\begin{array}{l}\text { Kemudahan mahasiswa untuk } \\
\text { mengerjakan dan mengirim tugas } \\
\text { yang diberikan }\end{array}$ & 4 & BAGUS \\
\hline 9. & $\begin{array}{l}\text { Kemudahan mahasiswa memperoleh } \\
\text { informasi dari bahan ajar yang } \\
\text { digunakan }\end{array}$ & 4 & BAGUS \\
\hline 10. & $\begin{array}{l}\text { Kemudahan mahasiswa untuk } \\
\text { membuat kesimpulan dari apa yang } \\
\text { dipelajari }\end{array}$ & 4 & BAGUS \\
\hline & Rekomendasi & Laya & digunakan \\
\hline
\end{tabular}

Hasil ini menunjukkan rancangan pembelajaran yang dibuat dapat digunakan dalam proses pembelajaran dengan memperbaiki indikator kemudahan petunjuk penggunaan bahan ajar.

\section{Hasil Observasi dan Agket Respon Mahasiswa terhadap Pembelajaran}

Tabel 8 adalah hasil observasi yang dilakukan teman sejawat (dosen) terhadap kegiatan pembelajaran yang telah dilakukan.

Pada tabel 8 menunjukkan bahwa pembelajaran dapat dilaksanakan dengan baik. Bahan ajar yang digunakan dapat dimanfaatkan dengan baik artinya semua tahapan yang telah dibuat dalam rancangan pembelajaran dapat dijalankan dengan baik. Kegiatan pembelajaran diikuti oleh 36 mahasiswa. Untuk melihat respon mahasiswa terhadap proses pembelajaran dapat dilihat dari 8 pernyataan yang mewakili tanggapan mahasiswa terhadap pembelajaran.

Berdasarkan hasil observasi terhadap pembelajaran yang dilakukan didapatkan bahwa proses pembelajaran berjalan sesuai dengan rencana pembelajaran yang dibuat. Hal ini menunjukkan bahwa bahan ajar yang dibuat dapat dimanfaatkan dengan baik dalam pembelajaran mata kuliah konsep dasar matematika materi sistem persamaan linear tiga variabel. 
Hasil ini juga didukung dengan hasil angket respon mahasiswa terhadap pembelajaran yang dilakukan didapatkan skor 3.69 dengan kategori senang terhadap pembelajaran yang diberikan. Selain itu kegiatan pembelajaran juga dapat meningkatkan hasil belajar matematika mahasiswa. Rata-rata nilai pretes sebesar 40.71 dengan nilai maksimum 75 meningkat menjadi 78.57 dengan nilai maksimum 100 .

Tabel 8 Hasil Observasi Kegiatan Pembelajaran

\begin{tabular}{|c|c|c|c|}
\hline \multirow{2}{*}{ NO } & \multirow{2}{*}{ KEGIATAN PEMBELAJARAN } & \multicolumn{2}{|c|}{ KATEGORI } \\
\hline & & $\mathbf{Y A}$ & TIDAK \\
\hline 1 & $\begin{array}{l}\text { Memberikan penjelasan tentang kegiatan } \\
\text { pembelajaran yang akan dilaksanakan yaitu } \\
\text { menggunakan sarana Flexible- Learning dan } \\
\text { Bahan Ajar Elektronik Berbasis Multimedia }\end{array}$ & $\mathrm{V}$ & \\
\hline 2 & $\begin{array}{l}\text { Menjelaskan tujuan pembelajaran yang akan } \\
\text { dicapai untuk memberikan motivasi kepada } \\
\text { mahasiswa dan pedoman penggunaan bahan ajar } \\
\text { elektronik yang telah disiapkan }\end{array}$ & $\mathrm{V}$ & \\
\hline 3 & $\begin{array}{l}\text { Memberikan rumusan masalah pada tampilan } \\
\text { awal di Flexible- Learning sebagai acuan } \\
\text { kegiatan dan fokus dari materi yang akan } \\
\text { dipelajari }\end{array}$ & $\mathrm{V}$ & \\
\hline 4 & $\begin{array}{l}\text { Dosen mengarahkan peserta didik untuk } \\
\text { membuka bahan ajar elektronik yang sudah } \\
\text { disiapkan di Flexible- Learning }\end{array}$ & $\mathrm{V}$ & \\
\hline 5 & $\begin{array}{l}\text { Dosen mengarahkan mahasiswa untuk } \\
\text { melaksanakan eksplorasi }\end{array}$ & $\mathrm{V}$ & \\
\hline 6 & $\begin{array}{l}\text { Dosen dan mahasiswa melaksanakan tanya } \\
\text { jawab terkait dengan hasil eksplorasi yang } \\
\text { dilSayakan oleh mahasiswa }\end{array}$ & $\mathrm{V}$ & \\
\hline 7 & $\begin{array}{l}\text { Dosen bersama mahasiswa membahas materi } \\
\text { yang telah diberikan berdasarkan hasil eksplorasi } \\
\text { dan diskusi bersama }\end{array}$ & $\mathrm{V}$ & \\
\hline 8 & $\begin{array}{l}\text { Dosen bersama mahasiswa menyimpulkan } \\
\text { pembelajaran yang telah dilaksanakan }\end{array}$ & $\mathrm{V}$ & \\
\hline 9 & $\begin{array}{l}\text { Mahasiswa mengerjakan evaluasi yang telah } \\
\text { disediakan dalam bahan ajar elektronik }\end{array}$ & $\mathrm{V}$ & \\
\hline 10 & $\begin{array}{l}\text { Dosen menyampaikan rencana kegiatan yang } \\
\text { akan dilaksanakan pada pertemuan berikutnya }\end{array}$ & $\mathrm{V}$ & \\
\hline
\end{tabular}


Tabel 9 Hasil angket respon mahasiswa terhadap proses pembelajaran

\begin{tabular}{|c|c|c|c|}
\hline No & Pernyataan & $\begin{array}{l}\text { Total } \\
\text { Skor }\end{array}$ & $\begin{array}{l}\text { Rata-Rata } \\
\text { Setiap item }\end{array}$ \\
\hline 1 & Saya senang pelajaran Matematika yang baru saja dilakukan & 148 & 4.11 \\
\hline 2 & $\begin{array}{l}\text { Saya ingin tahu lebih jauh tentang Matematika jika pembelajaran } \\
\text { Matematika seperti yang baru saja dilakukan }\end{array}$ & 144 & 4.00 \\
\hline 3 & Saya bersemangat dalam belajar Matematika & 132 & 3.67 \\
\hline 4 & $\begin{array}{l}\text { Saya lebih leluasa untuk belajar matematika dengan pembelajaran } \\
\text { seperti ini }\end{array}$ & 120 & 3.36 \\
\hline 5 & $\begin{array}{l}\text { Saya lebih mudah belajar dengan animasi yang diberikan dalam } \\
\text { menjelaskan konsep Matematika }\end{array}$ & 121 & 3.36 \\
\hline 6 & $\begin{array}{l}\text { Saya dapat memahami materi dengan mudah pada pembelajaran } \\
\text { Matematika ini }\end{array}$ & 112 & 3.11 \\
\hline 7 & Saya lebih mudah mengerjakan tugas dalam pembelajaran ini & 138 & 3.83 \\
\hline 8 & Saya lebih mudah mengikuti evaluasi dengan pembelajaran ini & 147 & 4.08 \\
\hline \multicolumn{3}{|c|}{ Total } & 29.50 \\
\hline \multicolumn{3}{|c|}{ Rata-Rata dari skor total } & 3.69 \\
\hline
\end{tabular}

\section{PENUTUP}

Berdasarkan hasil pembahasan yang dilakukan, maka dapat disimpulkan bahwa bahan ajar elektronik berbasis multimedia dengan macromedia Flash 8 yang dibuat memiliki kategori yang baik dari segi materi maupun media. Bahan ajar ini dapat membantu memudahkan mahasiswa belajar tentang sistem persamaan linear tiga variabel menggunakan fasilitas Flexible Learning.

Pemanfaatan bahan ajar ini membuat mahasiswa lebih senang belajar. Mahasiswa semakin mudah memahami materi karena bantuan animasi, video, warna dan tampilan yang menarik. Dengan bantuan tek, audio, dan video membuat mahasiswa dapat belajar secara mandiri, sehingga bahan ajar ini cocok digunakan sebagai bahan ajar mandiri yang dapat dibawa dan digunakan dimana-mana dan mahasiswa dapat belajar setiap saat. 


\section{DAFTAR PUSTAKA}

Andi Sapta. 2009. Pengertian Bahan Ajar . Materi diakses pada tanggal 12 Pebruari 2011 dari : http://andy-sapta.blogspot.com/2009/01/pengembangan-bahan-ajar-3.html

Ariesto Hadi Sutopo. 2008. Pengembangan Bahan Ajar Berbasis Multimedia. Jakarta: (modul kuliah)

Asra, Deni Darmawan \& Cepi Riana. 2007. Komputer dan Media Pembelajaran di SD. Jakarta: Dirjen Dikti

Cahya Prihandoko. 2006. Memahami konsep matematika secara benar dan menyajikannya dengan menarik. Jakarta: Departemen Pendidikan Nasional.

Dick \& Carey. 2005. The systematic Design of Instruction sixth Edition. Amerika: Allyn and Bacon.

Gagne, Robert M. 1977. The Conditions of Learning. New York: Holt, Rinehart and Winston.

Nyimas Aisyah. 2007. Pengembangan Pembelajaran Matematika SD. Jakarta: Dirjen Dikti.

Ruseffendi. 1993. Pendidikan matematika 3. Jakarta: Departemen Pendidikan dan Kebudayaan.

Sri Subarinah.2006. Pembelajaran Matematika Sekolah Dasar. Jakarta: Departemen Pendidikan Nasional

Suharno, Mulyoto, Sukamto. 2004. Pendekatan Cooperative dalam Pembelajaran Matematika ditinjau dari Kreativitas Peserta didik. Jurnal Teknodika. Vol 2. No 4. September 2004.

Suminarsih. 2007. Model-Model Pembelajaran Matematika. LPMP Jawa Tengah. 